\title{
Trichostrongylus colubriformis infection in Santa Inês lambs: impact on feed digestibility, blood markers, and nitrogen balance
}

\author{
Infecção por Trichostrongylus colubriformis em cordeiros Santa Inês: \\ impacto na digestibilidade dos alimentos, marcadores sanguíneos e \\ balanço de nitrogênio
}

\author{
Tairon Pannunzio Dias-Silva1* (1); Adibe Luiz Abdalla Filho²; Luciana Morita Katiki³; \\ Alessandro Francisco Talamini do Amarante4; Adibe Luiz Abdalla²; Helder Louvandini² \\ ${ }^{1}$ Universidade Federal do Piauí - UFPI, Campus Professora Cinobelina Elvas, Bom Jesus, PI, Brasil \\ ${ }^{2}$ Laboratório de Nutrição Animal, Centro de Energia Nuclear na Agricultura - CENA, Universidade de São Paulo - USP, Piracicaba, SP, \\ Brasil \\ ${ }^{3}$ Instituto de Zootecnia - IZ, Secretaria de Agricultura e Abastecimento - SAA, Nova Odessa, SP, Brasil \\ ${ }^{4}$ Instituto de Biociências, Universidade Estadual Paulista - UNESP, Botucatu, SP, Brasil
}

How to cite: Dias-Silva TP, Abdalla Filho AL, Katiki LM, Amarante AFT, Abdalla AL, Louvandini H. Trichostrongylus colubriformis infection in Santa Inês lambs: impact on feed digestibility, blood markers, and nitrogen balance. Braz J Vet Parasito/ 2020; 29(2): e002220. https://doi.org/10.1590/S1984-29612020026

\begin{abstract}
This study aimed to evaluate the effects of Trichostrongylus colubriformis infection on the hemato-biochemical parameters, feed digestibility, and nitrogen balance in Santa Inês lambs. Eighteen three-month-old Santa Ines castrated male lambs ( $16.9 \pm 1.43 \mathrm{~kg}$ of body weight) were randomly distributed in two experimental treatments: infected with $T$. colubriformis $(I, n=9)$ and uninfected $(U, n=9)$. The I group received a total of $45,000 L_{3}$ larvae of T. colubriformis (5,000 infective larvae, three times per week, for three weeks). During the experimental period, blood, feed digestibility, and nitrogen balance were evaluated. The I lambs showed a reduction in erythrocytes, hemoglobin, hematocrit, mean corpuscular volume, and total proteins, as well as an increase in platelets and eosinophils compared to those in the $U$ group $(p<0.05)$. With the exception of total protein content, these values were within the normal range for the species. Furthermore, lower dry matter and organic matter digestibility were observed in the I lambs $(p=0.08)$. The present findings highlight that $T$. colubriformis infection has the potential to impair some hemato-biochemical parameters as well as feed digestibility in lambs, which could affect their productivity.
\end{abstract}

Keywords: Parasites, feed digestibility, hematology, lambs.

\section{Resumo}

O objetivo deste estudo foi avaliar os efeitos da infecção por Trichostrongylus colubriformis nos parâmetros hemato-bioquímicos, digestibilidade aparente dos nutrientes e balanço de nitrogênio de cordeiros Santa Inês. Dezoito cordeiros Santa Inês, de três meses de idade e castrados (16,9 $\pm 1,43 \mathrm{~kg}$ de peso corporal), foram distribuídos aleatoriamente em dois tratamentos experimentais: infectados com T. colubriformis $(I, n=9)$ e não infectados $(U, n=9)$. $O$ grupo I recebeu um total de 45.000 larvas $L_{3}$ de $T$. colubriformis $(5.000$ larvas infectantes, três vezes por semana, durante três semanas). Durante o período experimental foram avaliadas as variáveis sanguíneas, digestibilidade e balanço de nitrogênio. Os cordeiros I apresentaram redução de eritrócitos, hemoglobina, hematócrito, volume corpuscular médio e proteínas totais, além de aumento de plaquetas e eosinófilos, quando comparados ao grupo $U(p<0,05)$. Contudo, exceto para proteínas totais, os valores estavam dentro do intervalo normal para a espécie. Além disso, a digestibilidade da matéria seca e da matéria orgânica foi menor no grupo I de cordeiros $(p=0,08)$. Os presentes achados destacam que a infecção por T. colubriformis teve potencial para prejudicar alguns parâmetros hemato-bioquímicos, bem como a digestibilidade aparente da dieta, o que poderia afetar a produtividade dos cordeiros.

Palavras-chave: Parasitas, digestibilidade do alimento, hematologia, cordeiros. 


\section{Introduction}

Gastrointestinal parasites are one of the main causes of economic losses in small ruminant production animals (Mondragón-Ancelmo et al., 2019), and the degree of infection can lead to low productivity, high mortality rate, and delay in the animal's body development. In this context, chronic and subclinical symptoms of parasite infection make it difficult to diagnose infections caused by Trichostrongylus colubriformis, which compromises sheep productivity through interference in the digestive and absorptive capacity of nutrients (Cantacessi et al., 2010; Silva et al., 2018, 2019). Consequently, promoting slow animal growth, a decrease in meat and wool production, and an increase in expenses associated with disease control.

Helminth infections in ruminants cause important hematological and biochemical changes, such as reduction in hemoglobin concentrations (Sotomaior \& Thomaz-Soccol, 1998), erythrocytes (Cardia et al., 2011), and in tissue oxygenation determining cells. They also cause an increase in immunoglobulins, mast cells, and leukocytes, both in blood and tissue levels (Harrison et al., 1999; Cardia et al., 2011). High total proteins exudation can also be verified (Kyriazakis et al., 1996).

In order to characterize the effects of infection by T. colubriformis (helminths with high prevalence around the world (O'Connor et al., 2006)) on lambs, it was hypothesized that the T. colubriformis infection can affect feed intake, apparent digestibility, blood markers, and meat production. Hence, as a complement of the previous study by Silva et al. (2019), we evaluated blood hemato-biochemical parameters, apparent nutrient digestibility, and nitrogen balance in lambs infected with $T$. colubriformis.

\section{Material and Methods}

\section{Experimental procedures}

The experimental procedures were conducted at the Laboratory of Animal Nutrition (LANA) at the Center for Nuclear Energy in Agriculture (CENA), Piracicaba, Brazil. The work was approved by the Animal Experimentation Ethics Committee (Protocol ID: 004/2015). Briefly, during an experimental period of 90 days, eighteen 90-day-old Santa Ines castrated male lambs and a mean initial body weight (BW) of $16.9 \pm 1.43 \mathrm{~kg}$ were randomly distributed into two groups: infected $(\mathrm{I}, n=9)$ and uninfected $(\mathrm{U}, n=9)$. Before starting the experimental period, lambs were dewormed and grouped using the pair-fed system. The I lambs were inoculated with $45,000 \mathrm{~L}_{3} \mathrm{~T}$. colubriformis larvae (5,000 infective larvae, three times per week, for three weeks), while the $U$ lambs did not receive $T$. colubriformus larvae inoculation. A more detailed description of lamb management aspects can be found in the report by Silva et al. (2019), and here we present some aspects not considered in our previous study.

\section{Diets}

The experimental diet was composed by Tifton hay (Cynodon spp.), concentrate (30\% soybean meal and $70 \%$ corn), and mineral mixture, in a proportion of 70:30 roughage:concentrate. Ingredients chemical composition analysis followed the procedures according to AOAC (2011) for dry matter (DM), organic matter (OM) and crude protein (CP), and Van Soest et al. (1991) and Mertens (2002) for neutral detergent fiber (NDF) and acid detergent fiber (ADF). The offered diet chemical composition was $\mathrm{DM}=90 \%, \mathrm{CP}=10.8 \%, \mathrm{NDF}=70.6 \%$ and $\mathrm{ADF}=32.4 \%$.

\section{Hematological and biochemical variables}

Blood samples were collected on days $0,15,30,45,60$, and 75 through jugular venipuncture using needles coupled to vacuum tubes (Becton-Dickson Indústria Cirúrgica, Curitiba, Brazil) containing $0.05 \mathrm{~mL}$ of ethylenediamine tetraacetic acid (EDTA) per $5 \mathrm{~mL}$ of blood. The number of erythrocytes $\left(10^{6} \mu \mathrm{L}\right)$, hematocrit $(\%)$, hemoglobin $(\mathrm{g} / \mathrm{dL})$, mean corpuscular volume (MCV, $\mathrm{fL})$, mean corpuscular hemoglobin $(\mathrm{MCH}, \mathrm{pg})$, concentration of mean corpuscular hemoglobin $(\mathrm{MCHC}, \mathrm{g} / \mathrm{dL})$, leukocytes $\left(10^{3} \mu \mathrm{L}\right)$, and platelets $\left(10^{3} \mu \mathrm{L}\right)$ were determined. All the blood variables were measured using an automated veterinary hematological analyzer (Sysmex pocH-100iV Diff).

"In natura" blood samples were used to obtained blood smears of each animal in each sampling period, for differential leukocyte count. After drying, these smears were stained using the Romanowsky type quick dye (Panótico rápido - Labor Clin ${ }^{\circledR}$ LTDA, Pinhais, Paraná, Brazil). In each blood smear, 100 leukocytes were differentiated classified and read under a microscope magnified by 100x, according to their morphological and tannic characteristics in neutrophils, eosinophils, basophils, lymphocytes, and monocytes. 
Additionally, blood samples $(5 \mathrm{~mL}$ ) were collected in vacuum tubes (Becton-Dickson Indústria Cirúrgica, Curitiba, Brazil) without anticoagulants and then centrifuged at $2000 \times \mathrm{g}$ for 10 minutes to obtain blood serum. The supernatant (serum) was collected and stored in polypropylene tubes at $20^{\circ} \mathrm{C}$ for determination of total proteins (TP) and albumin using commercial Labtest ${ }^{\circledR}$ kits and analyzed in an epoch microplate spectrophotometer (BioTek Instruments, Inc., Winooski, Vermont, EUA). The globulins and the albumin/globulin (A/G) ratio were measured through the determination of TP and albumin. Beta-hydroxybutyrate (BHB) acid was measured immediately after the blood sample collection, using a portable sensor Optium Xcedd (Abbott Diabetes Care Ltda., Witney, UK) according to the methodology described by Raimondo et al. (2011).

\section{Apparent nutrient digestibility and nitrogen balance}

Twenty days after the last inoculation of $\mathrm{L}_{3^{\prime}}$ animals from both groups were randomly distributed in metabolism study cages, where they stayed for 10 days. Daily samples of offered diet, leftovers, faeces, and urine were collected. Dietary, leftover, and faecal samples were weighed and a representative sample ( $10 \%$ of the total) was stored at $-20^{\circ} \mathrm{C}$. Urine samples were collected in buckets containing $100 \mathrm{~mL}$ of $10 \%$ sulfuric acid, with total volume determined in a graduated cylinder. A $10 \%$ sample was frozen for further analysis. Samples of offered diet, leftovers, and faeces were thawed, dried in a forced circulation oven at $60{ }^{\circ} \mathrm{C}$ for 48 hours, milled to $1 \mathrm{~mm}$ in a Willey-type mill, and subjected to chemical analysis as previously described. The apparent digestibility of each dietary unit was calculated according to the following Equation 1:

$\mathrm{AD}$ of $\mathrm{X}(\%)=[(\mathrm{X}$ ingested $-\mathrm{X}$ excreted $) / \mathrm{X}$ ingested $] \times 100$

Where $A D$ of $X$ is the apparent digestibility (AD) of the dietary unit analysed (X).

For nitrogen balance calculation, urine and faeces total $\mathrm{N}$ concentration $(\mathrm{N})$ was determined by the micro-Kjeldahl method (AOAC, 2011), using steam distillation with sodium hydroxide solution $12 \mathrm{M}(\mathrm{NaOH})$, collecting this in the solution of boric acid $\left(\mathrm{H}_{3} \mathrm{BO}_{3}\right)$ and titration with a solution of $0.025 \mathrm{M} \mathrm{H}_{2} \mathrm{SO}_{4}$. The nitrogen $(\mathrm{N})$ retained was calculated as the difference between the total $\mathrm{N}$ ingested and the total $\mathrm{N}$ excreted, as described in the following Equation 2:

$\mathrm{N}$ retained $=(\mathrm{N}$ ingested $)-(\mathrm{N}$ excreted $)$

Where $\mathrm{N}$ ingested is the amount $\mathrm{N}$ ingested from the offered diet and $\mathrm{N}$ excreted is the amount of $\mathrm{N}$ excreted in the faeces and urine.

\section{Data analysis}

The statistical analysis of the data was performed using the SAS program version 9.3 ${ }^{\circledR}$ (SAS Institute Inc., Cary, North Carolina, USA). Hemato-biochemical variables were subjected to analysis of variance using the MIXED procedure, with measures repeated over time. Apparent nutrient digestibility and nitrogen balance data were analyzed using the generalized linear model (GLM) procedure. The means were compared using the t test, adopting $5 \%$ probability. In the variables with measurements repeated over time, the effects of treatment, time, and the interaction treatment $\times$ time (periods) were tested.

\section{Results}

\section{Hemato-biochemical variables}

The I lambs exhibited reduced values of erythrocytes, hemoglobin, hematocrit, and MCV compared to U lambs $(p<0.05)$ (Table 1). On the other hand, MCHC and platelet count were higher in I lambs ( $p<0.05)$. Infection with T. colubriformus had no effect on the number of circulating leukocytes in I lambs compared to $U$ lambs $(p>0.05)$. However, the differential leukocyte test showed a significant increase in the number of eosinophils in response to infection by $T$. colubriformis, as well as the effect over time on the eosinophil count $(p<0.05)$. Infection with T. colubriformis reduced TP $(p<0.05)$ (Table 1). Blood concentrations of albumin, globulin, and beta-hydroxybutyrate as well as the $A / G$ ratio were unaffected by infection with $T$. colubriformis $(p>0.05)$. 
Table 1. Hematological and biochemical parameters of lambs uninfected and infected with Trichostrongylus colubriformis.

\begin{tabular}{|c|c|c|c|c|c|c|}
\hline \multirow{2}{*}{ Parameters } & \multirow{2}{*}{$\begin{array}{l}\text { Reference } \\
\text { values }^{1,2}\end{array}$} & \multicolumn{2}{|c|}{ Treatments } & \multicolumn{3}{|c|}{ Effects } \\
\hline & & Uninfected $(n=9)$ & Infected $(n=9)$ & Treat & Time & Treat×time \\
\hline Erythrocytes $\left(10^{6} / \mu \mathrm{L}\right)$ & $8-16^{1}$ & $13.1 \pm 0.25$ & $12.1 \pm 0.26$ & * & ns & ns \\
\hline Hematocrit (\%) & $24-50^{1}$ & $46.4 \pm 0.96$ & $41.9 \pm 1.01$ & * & ns & ns \\
\hline Hemoglobin (g/dL) & $8-16^{1}$ & $12.1 \pm 0.19$ & $11.3 \pm 0.20$ & * & ns & ns \\
\hline $\mathrm{MCV}(\mathrm{fL})$ & $23-48^{1}$ & $35.4 \pm 0.19$ & $34.4 \pm 0.20$ & * & ns & ns \\
\hline $\mathrm{MCH}(\mathrm{pg})$ & $9-13^{1}$ & $9.2 \pm 0.07$ & $9.3 \pm 0.07$ & ns & ns & ns \\
\hline $\mathrm{MCHC}(\mathrm{g} / \mathrm{dL})$ & $29-35^{1}$ & $26.2 \pm 0.23$ & $27.1 \pm 0.24$ & * & ns & ns \\
\hline Platelets $\left(10^{3} / \mu \mathrm{L}\right)$ & $200-700^{1}$ & $593.4 \pm 23.09$ & $680.5 \pm 24.17$ & * & * & ns \\
\hline Leukocytes $\left(10^{3} / \mu \mathrm{L}\right)$ & $4-12^{1}$ & $10.1 \pm 0.35$ & $10.1 \pm 0.36$ & ns & * & ns \\
\hline Neutrophils / $\mu \mathrm{L}$ & $600-4000^{1}$ & $4938.9 \pm 1.45$ & $4777.3 \pm 1.45$ & ns & ns & ns \\
\hline Lymphocytes / $\mu \mathrm{L}$ & $2500-7500^{1}$ & $4514.7 \pm 1.6$ & $4151.1 \pm 1.6$ & ns & * & ns \\
\hline Eosinophils / $\mu \mathrm{L}$ & $0-2400^{1}$ & $191.9 \pm 0.55$ & $868.6 \pm 0.55$ & * & * & ns \\
\hline Monocytes $/ \mu \mathrm{L}$ & $250-840^{1}$ & $383.8 \pm 0.48$ & $363.6 \pm 0.48$ & ns & * & ns \\
\hline Basophils / $\mu \mathrm{L}$ & --- & $30.3 \pm 0.09$ & $40.4 \pm 0.09$ & ns & * & ns \\
\hline Total Proteins (g/dL) & $6-7.9^{2}$ & $6.8 \pm 0.19$ & $5.8 \pm 0.18$ & * & ns & ns \\
\hline Albumins (g/dL) & $2.4-3^{2}$ & $2.7 \pm 0.09$ & $2.5 \pm 0.09$ & ns & ns & ns \\
\hline Globulins (g/dL) & $3.1-5.1^{2}$ & $4.0 \pm 0.27$ & $3.4 \pm 0.19$ & ns & ns & ns \\
\hline $\mathrm{A} / \mathrm{G}$ ratio & $0.4-0.7^{2}$ & $0.6 \pm 0.03$ & $0.7 \pm 0.03$ & ns & ns & ns \\
\hline $\mathrm{BHB}(\mathrm{mmol} / \mathrm{L})$ & $<0.6^{2}$ & $0.4 \pm 0.02$ & $0.4 \pm 0.02$ & ns & ns & ns \\
\hline
\end{tabular}

${ }^{1}$ Reference values according to Kramer (2006); ${ }^{2}$ Reference values according to Kaneko et al. (2008); MCV- Mean corpuscular volume; MCH- Mean corpuscular hemoglobin; MCHC- Mean corpuscular hemoglobin concentration; A/G ratio - albumins/globulins ratio; BHB - beta-hydroxybutyrate; Treat- effect of treatment; Time - effect of time; Treatxtime - Interaction between treatment and time; * t-test significance at $5 \%$ probability; ns - not significant.

\section{Apparent nutrient digestibility and nitrogen balance}

The apparent digestibility of DM, OM, CP, NDF, and ADF showed no difference between infected and uninfected lambs (Table 2). In addition, no difference between infected and uninfected lambs was observed for $\mathrm{N}$ intake and excretion, and consequently $\mathrm{N}$ retention was not affected by the infection (Table 2).

Table 2. Apparent nutrient digestibility and nitrogen balance in lambs uninfected and infected with Trichostrongylus colubriformis.

\begin{tabular}{|c|c|c|c|}
\hline \multirow{2}{*}{ Apparent digestibility (\%) } & \multicolumn{2}{|c|}{ Treatments } & \multirow{2}{*}{ Effect } \\
\hline & Uninfected $(n=9)$ & Infected $(n=9)$ & \\
\hline Dry matter & $61.3 \pm 0.02$ & $55.8 \pm 0.02$ & ns \\
\hline Organic matter & $62.8 \pm 0.02$ & $56.7 \pm 0.02$ & ns \\
\hline Crude protein & $64.1 \pm 0.02$ & $60.8 \pm 0.02$ & ns \\
\hline Neutral detergent fiber & $59.3 \pm 0.03$ & $52.4 \pm 0.03$ & ns \\
\hline Acid Detergent Fiber & $48.1 \pm 0.04$ & $41.4 \pm 0.04$ & ns \\
\hline Nitrogen ingested (diet) & $10.7 \pm 0.83$ & $10.9 \pm 0.83$ & ns \\
\hline Nitrogen excreted in faeces & $3.8 \pm 0.33$ & $4.4 \pm 0.33$ & ns \\
\hline Nitrogen excreted in urine & $2.38 \pm 0.28$ & $3.06 \pm 0.28$ & ns \\
\hline Nitrogen retained & $4.54 \pm 0.71$ & $3.47 \pm 0.71$ & ns \\
\hline
\end{tabular}

t-test significance at 5\% probability; ns - not significant 


\section{Discussion}

The lambs in the I group were characterized by a moderate (Ueno \& Gonçalves, 1998) infection with T. colubriformis, verified by eggs in faeces 30 days after the initial infection and a few lambs with clinical signs. A more detailed description of lamb infection during the experimental period can be found in the report by Silva et al. (2019). These results are characteristic of animals infected with $T$. colubriformis, as previously reported by Silva et al. (2018). $T$. colubriformis infection caused a reduction in erythrocyte, hemoglobin, hematocrit, and MCV values in infected lambs, but it is important to note that these values were within the normal range for the species (Kramer, 2006). When these values are lower than the normal range, a reduction in the transport of oxygen and nutrients to the tissues, as described by Jain (1986), can occur. The high number of blood platelets in infected lambs, although still within the normal range (Kramer, 2006), may indicate a response to bleeding, as a consequence of the formation of tunnels and erosion in the duodenal mucosa epithelium, due to implantation and larval establishment (Bowman, 2003). The values of MCHC were also within the normal range (Kramer, 2006); however, higher MCHC in infected lambs may have been a result of an increase in hemoglobin concentration in the erythrocytes, or could indicate a possible nutritional deficiency as a result of the effects of the infection (Kramer, 2006).

Infected lambs showed an increase in the number of circulating eosinophil's compared to uninfected lambs. This eosinophilic response is characteristic of animals infected by endoparasites, producing immediate response against T. colubriformis infections (Cardia et al., 2011). The higher eosinophil counts were recorded at 60 and 75 days after initial infection, when the faecal egg count decreased from 1.188 at 45 days to 572 at 60 days and 561 at 75 days (data presented in Silva et al. 2019), indicating active immune response against parasitic infection corroborating with the related by Dorchies et al. (1997), but again, those values were within the normal range (Kramer, 2006). In both groups, the variables albumin, globulin and A/G ratio were within the reference values proposed by Kaneko et al. (2008). However, TP were significantly lower in infected lambs, slightly below the reference for the species. The reduction of TP is usually associated with large intestinal mucosa microvilli atrophy, formation of tunnels, and duodenal mucosa epithelium erosion (Cardia et al., 2011), hyperplasia and crypts hypertrophy (Cardia et al., 2011) as well as the occurrence of high exudation of serum proteins to the intestinal lumen imposed by T. colubriformis. Regarding energetic metabolites, there was no change in BHB levels between treatments which were within the normal range for the species (Kaneko et al., 2008).

Regarding apparent digestibility of nutrients, the level of larval challenge and the number of worms established during infection tend to impair digestibility and nutrient absorption by animals (Van Houtert \& Sykes, 1996). Usually, animals infected with gastrointestinal parasites, show reduction in nutrient availability, due to the decreased voluntary intake and a reduction in digestive capacity and efficiency in absorption of nutrients (Dynes et al., 1998), being these dependent on the infecting nematode species. In the case of $T$. colubriformis, the reduction of the animal performance was associated with reduction of the digestive and absorptive capacity of the nutrients (Silva et al., 2019), as seen in the present study regarding a numerically lower DM and OM digestibility. In these circumstances, the larval establishment is the main cause, promoting damage in the absorptive mucosa such as generalized atrophy of the villi and duodenal epithelial erosion, affecting nutrient absorption capacity (Coop et al., 1982; Coop \& Kyriazakis, 1999; Cardia et al., 2011). Evaluation of the digestibility of dietary fractions (CP, NDF, and ADF) showed similar results between the I and U groups; however, two points should be taken into account. First, due to individual variation, only two lambs ( $22 \%$ of the I group) showed high parasitic load (faecal egg counts from 350 to 2400 reported in Silva et al. 2019), which may have contributed to the statistical insignificance between the groups. This variation among animals is common in sheep under grazing management. Second, CP digestion and compensatory absorption may be facilitated in infected lambs, whereby they are able to alter their intestinal absorption site, resulting in better nutrient assimilation (Bown et al., 1991). Our results are supported by the findings of Symons and Jones (1970) and Poppi et al. (1986), who observed no influence of T. colubriformis infection on the digestion and protein absorption in sheep because of their ability to absorb nutrients in different intestinal sites. Similarly, the $\mathrm{N}$ balance was not affected by $T$. colubriformis infection, possibly because of compensatory absorption as previously mentioned.

\section{Conclusions}

Lambs infected with T. colubriformis resulted in an impact on blood markers; however, except the total protein content values, these variations were within normal range for the species. Additionally, a tendency to reduction in apparent digestibility of dry and organic matter was observed in infected lambs, which could be another reason for lower animal growth rates and meat production under these infectious conditions (Silva et al., 2019). 


\section{Acknowledgements}

The authors would like to thank the National Council of Technological and Scientific Development (CNPq), Coordination for the Improvement of Higher Education Personnel (CAPES) and São Paulo Research Foundation (FAPESP) for providing financial support (process number 2014/05023-1).

\section{References}

Association of Official Analytical Chemists - AOAC. Official methods of analysis. 18th ed. Arlington: AOAC International; 2011.

Bowman DD. Georgis' parasitology for veterinarians. 8th ed. St. Louis, Missouri: Saunders Publishing; 2003. 422 p.

Bown MD, Poppi DP, Sykes AR. Nitrogen transactions along the digestive tract of lambs concurrently infected with Trichostrongylus colubriformis and Ostertagia circumcincta. BrJ Nutr 1991; 66(2): 237-249. http://dx.doi.org/10.1079/BJN19910028. PMid:1760444.

Cantacessi C, Mitreva M, Campbell BE, Hall RS, Young ND, Jex AR, et al. First transcriptomic analysis of the economically important parasitic nematode, Trichostrongylus colubriformis, using a next-generation sequencing approach. Infect Genet Evol 2010; 10(8): 1199-1207. http://dx.doi.org/10.1016/j.meegid.2010.07.024. PMid:20692378.

Cardia DFF, Rocha-Oliveira RA, Tsunemi MH, Amarante AFT. Immune response and performance of growing Santa Ines lambs to artificial Trichostrongy/us colubriformis infections. Vet Parasitol 2011; 182(2-4): 248-258. http://dx.doi.org/10.1016/j. vetpar.2011.05.017. PMid:21641720.

Coop RL, Kyriazakis I. Nutrition-parasite interaction. Vet Parasitol 1999; 84(3-4): 187-204. http://dx.doi.org/10.1016/S03044017(99)00070-9. PMid:10456415.

Coop RL, Sykes AR, Angus KW. The effect of three levels of intake of Ostertagia circumcincta larvae on growth rate, food intake and body composition of growing lambs. J Agric Sci 1982; 98(2): 247-255. http://dx.doi.org/10.1017/S0021859600041782.

Dorchies P, Bergeaud JP, Khanh NV, Morand S. Reduced egg counts in mixed infections with Oestrus ovis and Haemonchus contortus: influence of eosinophils? Parasitol Res 1997; 83(7): 727-730. http://dx.doi.org/10.1007/s004360050328. PMid:9272567.

Dynes RA, Poppi DP, Barrell GK, Sykes AR. Elevation of feed intake in parasite-infected lambs by central administration of a cholecystokinin receptor antagonist.D. Br J Nutr 1998; 79(1): 47-54. http://dx.doi.org/10.1079/BJN19980008. PMid:9505802.

Harrison GBL, Pulford HD, Gatehouse TK, Shaw RJ, Pfeffer A, Shoemaker CB. Studies on the role of mucus and mucosal hypersensitivity reactions during rejection of Trichostrongylus colubriformis from the intestine of immune sheep using an experimental challenge model. Int J Parasitol 1999; 29(3): 459-468. http://dx.doi.org/10.1016/S0020-7519(98)00221-5. PMid:10333330.

Jain NC. Schalm's veterinary hematology. 4th ed. Philadelphia: Lea \& Febiger; 1986.

Kaneko JJ, Harvey JW, Bruss ML. Clinical biochemistry of domestic animal. 6th ed. San Diego: Academic Press; 2008.

Kramer JW. Normal hematology of cattle, sheep, and goats. In: Feldman BF, ZinkI JG, Jain NC, editors. Schalm's veterinary hematology. 5th ed. Ames: Blackwell; 2006.

Kyriazakis I, Anderson DH, Oldham JD, Coop RL, Jackson F. Long-term subclinical infection with Trichostrongylus colubriformis: effects on food intake, diet selection and performance of growing lambs. Vet Parasitol 1996; 61(3-4): 297-313. http://dx.doi. org/10.1016/0304-4017(95)00824-1. PMid:8720567.

Mertens DR. Gravimetric determination of amylase-treated neutral detergent fiber in feeds with refluxing in beaker or crucibles: collaborative study. J AOAC Int 2002; 85(6): 1217-1240. PMid:12477183.

Mondragón-Ancelmo J, Olmedo-Juárez A, Reyes-Guerrero DE, Ramírez-Vargas G, Ariza-Román AE, López-Arellano ME, et al. Detection of Gastrointestinal Nematode Populations Resistant to Albendazole and Ivermectin in Sheep. Animals (Basel) 2019; 9(10): 775. http://dx.doi.org/10.3390/ani9100775. PMid:31658591.

O'Connor LJ, Walkden-Brown SW, Kahn LP. Ecology of the free-living stages of major trichostrongylid parasites of sheep. Vet Parasitol 2006; 142(1-2): 1-15. http://dx.doi.org/10.1016/j.vetpar.2006.08.035. PMid:17011129.

Poppi DP, MacRae JC, Brewer A, Coop RL. Nitrogen transactions in the digestive tract of lambs exposed to the intestinal parasite Trichostrongylus colubriformis. Br J Nutr 1986; 55(3): 593-602. http://dx.doi.org/10.1079/BJN19860064. PMid:3314979.

Raimondo RFS, Raimondo RFS, Yasuoka MM, Hagiwara MK, Birgel EH Jr, Miyashiro SI. Uso de sensor portátil para a mensuração de glicose e beta hidroxibutirato no sangue de bovinos leiteiros. Vet Zootec 2011; 18: 389-393.

Silva TPD, Jimenez CR, leda EH, Abdalla AL, Louvandini H. Phosphorus kinetics in lambs experimentally infected with Trichostrongy/us colubriformis with the use of ${ }^{32}$ P. Exp Parasito/ 2018; 188: 13-20. http://dx.doi.org/10.1016/j.exppara.2018.03.011. PMid:29555416. 
Silva TPD, Ventoso Bompadre TF, Danasekaran DK, Sakita GZ, Abdalla Filho AL, Jimenez CR, et al. Trichostrongylus colubriformis infection: impact on digesta passage rate and lamb performance. Vet Parasito/ 2019; 272: 17-22. http://dx.doi.org/10.1016/j. vetpar.2019.06.018. PMid:31395200.

Sotomaior CS, Thomaz-Soccol V. Estudo do tipo de hemoglobina como auxiliar na seleção de ovinos resistentes e susceptíveis aos helmintos gastrointestinais. Arch Vet Sci 1998; 3(1): 51-55.

Symons LEA, Jones WO. Nematospiroides dubius, Nippostrongylus brasiliensis and Trichostrongylus colubriformis: protein digestion in infected mammals. Exp Parasitol 1970; 27(3): 496-506. http://dx.doi.org/10.1016/0014-4894(70)90053-6. PMid:5419458.

Ueno H, Gonçalves PC. Manual para diagnóstico das helmintoses de ruminantes. 4. ed. Tokyo: Japan International Cooperation Agency; 1998. 143 p.

Van Houtert MFJ, Sykes AR. Implications of nutrition for the ability of ruminants to withstand gastrointestinal nematode infections. Int J Parasitol 1996; 26(11): 1151-1167. http://dx.doi.org/10.1016/S0020-7519(96)00120-8. PMid:9024860.

Van Soest PJ, Robertson JB, Lewis BA. Methods for dietary fiber, neutral detergent fiber, and nonstarch polysaccharides in relation to animal nutrition. J Dairy Sci 1991; 74(10): 3583-3597. http://dx.doi.org/10.3168/jds.S0022-0302(91)78551-2. PMid:1660498. 